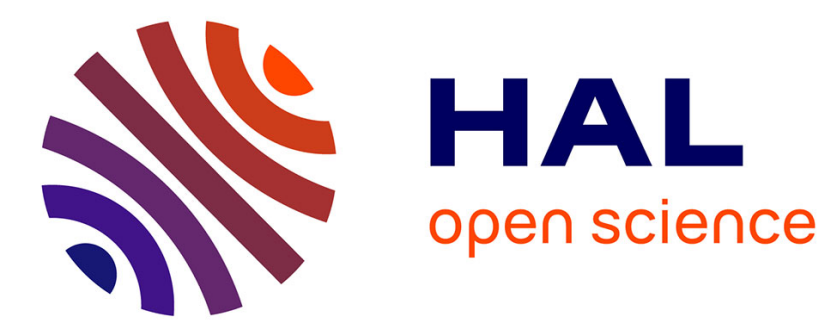

\title{
XAFS Characterization of Copper Contamination in the Unsaturated and Saturated Zones of a Soil Profile
}

\author{
D. Sayers, D. Hesterberg, W. Zhou, W. Robarge, G. Plurnmer
}

\section{To cite this version:}

D. Sayers, D. Hesterberg, W. Zhou, W. Robarge, G. Plurnmer. XAFS Characterization of Copper Contamination in the Unsaturated and Saturated Zones of a Soil Profile. Journal de Physique IV Proceedings, 1997, 7 (C2), pp.C2-831-C2-832. 10.1051/jp4:1997252 . jpa-00255331

\section{HAL Id: jpa-00255331 https://hal.science/jpa-00255331}

Submitted on 1 Jan 1997

HAL is a multi-disciplinary open access archive for the deposit and dissemination of scientific research documents, whether they are published or not. The documents may come from teaching and research institutions in France or abroad, or from public or private research centers.
L'archive ouverte pluridisciplinaire HAL, est destinée au dépôt et à la diffusion de documents scientifiques de niveau recherche, publiés ou non, émanant des établissements d'enseignement et de recherche français ou étrangers, des laboratoires publics ou privés. 


\title{
XAFS Characterization of Copper Contamination in the Unsaturated and Saturated Zones of a Soil Profile
}

\author{
D.E. Sayers, D. Hesterberg*, W. Zhou, W.P. Robarge* and G.M. Plummer \\ Department of Physics, Box 7518, North Carolina State University, Raleigh NC 27695, U.S.A. \\ * Department of Soil Science, Box 7619, North Carolina State University, Raleigh NC 27695, U.S.A.
}

\begin{abstract}
The fate of heavy-metal contaminants in the environment, and the design and success of remediation strategies at hazardous waste sites depend on the chemical speciation of the contaminants. The objective of this study was to determine the molecular-scale chemical form (species) of heavy metals in different zones of a contaminated soil having a shallow ground water table. Copper in the unsaturated surface horizon and the water-saturated and partially-saturated subsurface horizons of a disturbed soil from the lower eastern coastal plain of North Carolina was characterized using XAFS spectroscopy. Extended $x$-ray absorption fine structure (EXAFS) and $x$-ray absorption near edge structure (XANES) data showed that the dominant form of $\mathrm{Cu}(\mathrm{II})$ bonding ranged from $\mathrm{Cu}-\mathrm{S}$ in the deeper soil zones to $\mathrm{Cu}-\mathrm{O}$ in the shallowest zone. The results suggest that the surface and subsurface horizons will respond differently to remediation treatments.
\end{abstract}

\section{INTRODUCTION}

Chemical speciation is one of the more important factors affecting the solubility, fate, and treatability of heavy-metal contaminants in the environment. XAFS spectroscopy has the potential for providing molecular-scale speciation of metals occurring at low concentrations in complex media such as soils. The objective of this study was to determine the chemical forms (species) of copper occurring at different depths in a contaminated soil in the lower eastern coastal plain of North Carolina, USA. Because the saturated zone of this soil is at $\sim 1 \mathrm{~m}$, redox potential was expected to play a significant role in metal speciation, particularly with regard to metal-sulfide formation. Previous research showed that XAFS is particularly useful for identifying metal sulfides in soils, because of the larger ionic radius of $\mathrm{S}^{2-}$ relative to $\mathrm{O}^{2-}[1]$.

\section{MATERIALS AND METHODS}

Soil samples were collected from three depth intervals at a metal-contaminated site on the Marine Corps Air Station in Cherry Point, North Carolina: $28-56 \mathrm{~cm}, 56-71 \mathrm{~cm}$, and $71-86 \mathrm{~cm}$. These intervals approximately represent an unsaturated zone of strong brown color (7.5YR 5/8), a black colored (7.5YR 2/0) zone that possibly experiences intermittent water saturation, and a black colored (7.5YR 2/0) water-saturated zone. The site is a disturbed area that was used for landfilling. Samples were sieved to $<2-\mathrm{mm}$ particle size to remove debris, freeze-dried, then crushed to pass a 125- $\mu \mathrm{m}$ stainless-steel sieve. XAFS analyses were done at Beamline X-11A at the National Synchrotron Light Source, Brookhaven National Laboratory. Samples were analyzed in fluorescence mode at the $\mathrm{Cu}$ K-edge $(8,979 \mathrm{eV})$ using a multielement detector. Data analyses were completed using $\mathrm{CuO}$ (tenorite, first-shell bond length - $\mathrm{r}_{\mathrm{Cu}-\mathrm{O}}=1.95 \AA$ ) and $\mathrm{CuS}$ (covellite, $\mathrm{r}_{\mathrm{Cu}-\mathrm{S}}=2.25 \AA$ ) as standards. Fourier transforms of EXAFS spectra were done over the wavevector range $\mathrm{k}=3.0-10.2 \AA^{-1}$, and model fitting was done over the radial distance ranges $R=0.8-2.2 \AA$ for the $28-56 \mathrm{~cm}$ sample and $R=0.8-2.5 \AA$ for the two deeper samples.

\section{RESULTS AND DISCUSSION}

Figures 1 and 2 show radial structure functions (RSFs) and XANES spectra for the soil samples and selected standards, including a sample of $\mathrm{Cu}$ bound with humic acid [2]. RSFs for the soil samples exhibit a broad 1st-shell peak that shifts from about $1.6 \AA$ to $1.85 \AA$ between the shallowest and deeper samples (Fig. 1). These radial distances approximately correspond with first-shell peaks for standards having $\mathrm{Cu}-\mathrm{O}$ bonding [ $\mathrm{CuO}$ and $\mathrm{Cu}$ bound to humic acid] and $\mathrm{Cu}-\mathrm{S}$ bonding (CuS), and indicate that $\mathrm{Cu}(\mathrm{II})$ in the two deeper soil samples is predominantly $\mathrm{Cu}-\mathrm{S}$ bonded (presumably $\mathrm{CuS}$ ). Based on relative coordination numbers $\mathrm{Cu}-\mathrm{O}$ and $\mathrm{Cu}-\mathrm{S}$ bonding derived from EXAFS data fitting [1], the following percentages of $\mathrm{Cu}-\mathrm{S}$ bonding were calculated for the soil samples: $36 \%(28-56 \mathrm{~cm}), 77 \%(56-71 \mathrm{~cm})$, and $81 \%(71-86 \mathrm{~cm})$. Based on the standard errors calculated for fitting parameters, we estimate that the accuracy of these data is $\pm 10 \%$. XANES results (Fig. 2) show a high degree of similarity between spectra for $\mathrm{Cu}$ (II) in the two deeper soil samples and the CuS standard, while the shallowest soil sample was more similar to the oxygen-bonded standards. These results are consistent with the EXAFS data. 


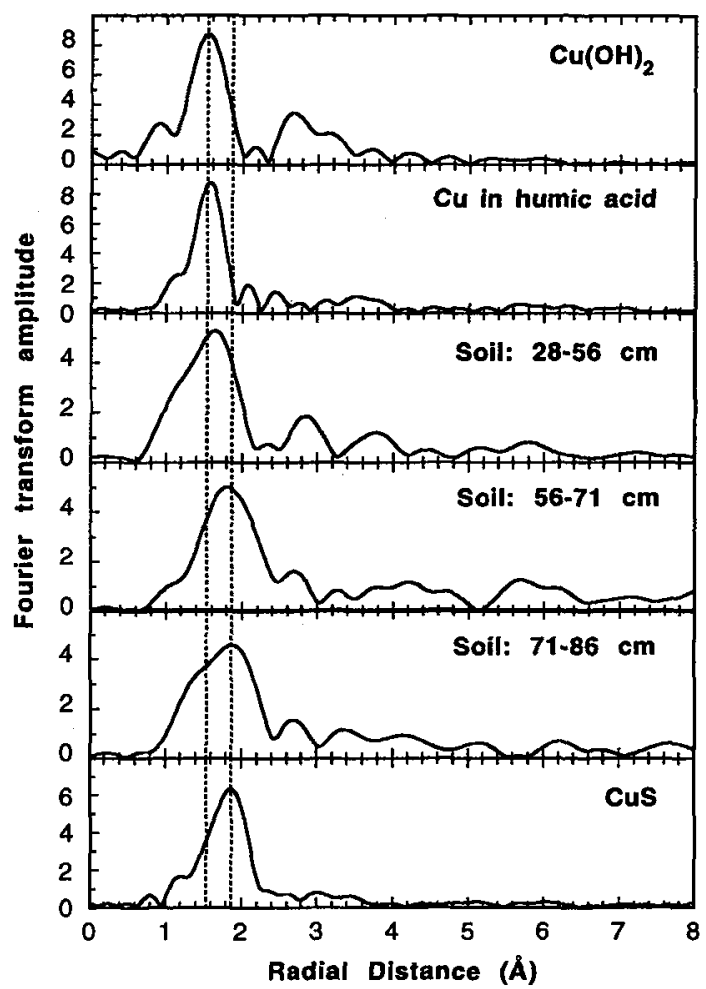

Figure 1: Radial structure functions for $\mathrm{Cu}$ (II) in soil samples from different depths and selected standards. Data are not corrected for phase shift; therefore, peaks do not represent exact bond lengths. Vertical lines are eye guides.

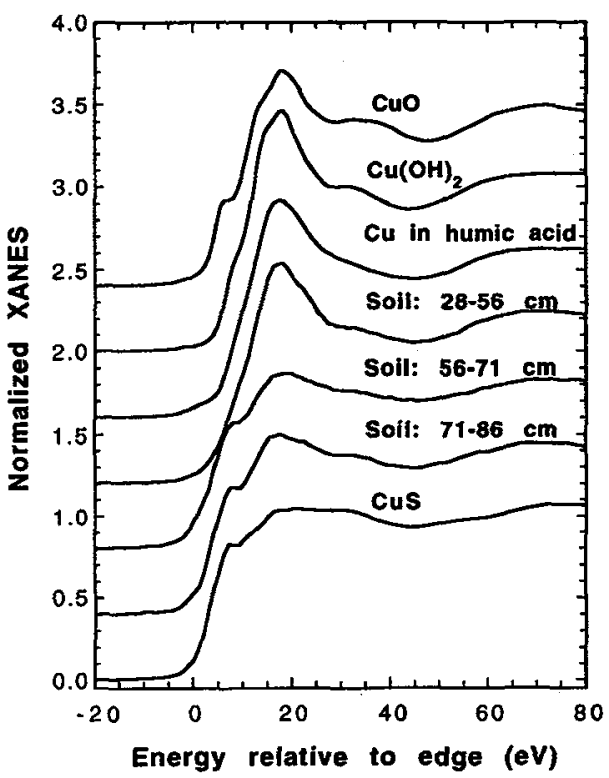

Figure 2: Stacked XANES spectra for $\mathrm{Cu}(\mathrm{II})$ in soil samples and selected standards.

The classical method for operationally speciating heavy metals in soils is by sequential chemical extractions. A sequential chemical extraction analysis was done on the soil samples using the following extractants: (i) $0.5 \mathrm{M}$ KNO3, (ii) deionized water, (iii) $0.04 \underline{\mathrm{M} \mathrm{NH}} 2 \mathrm{OH} \cdot \mathrm{HCl}$, (iv) $0.5 \underline{\mathrm{M} \mathrm{NaOH}}$, and $4 \underline{\mathrm{M}} \mathrm{HNO}_{3}$ at $80^{\circ} \mathrm{C}(3,4)$. We found an increase in hot $\mathrm{HNO}_{3}$ - extractable $\mathrm{Cu}$ between the shallowest zone $(71 \pm 4 \%$ of total $\mathrm{Cu})$ and the two deeper zones $(87 \pm 1 \%$ and $89.7 \pm$ $0.7 \%$ ). This extractant targets metal sulfides and other residual species. Because XAFS results indicated that there was only about $36 \% \mathrm{Cu}-\mathrm{S}$ bonding in the shallow zone, much of the $\mathrm{HNO}_{3}$-extractable $\mathrm{Cu}$ in this zone apparently occurs in some other residual fraction. The fact that $\mathrm{CuS}$ and oxygen-bonded $\mathrm{Cu}(\mathrm{II})$ should react differently to changing soil redox potential or $\mathrm{pH}$ conditions [5] illustrates the advantage of XAFS spectroscopy over chemical extractions for determining metal speciation and potential fate of metals in soils.

\section{Acknowledgments}

The authors are grateful to Paul Hansen for completing the chemical extraction analyses, and to Renee Henderson and the Environmental Affairs Department at the Marine Corps Air Station in Cherry Point, NC for their cooperation in selecting sampling sites and collecting samples for this study. This work is supported by the US Department of Energy, Division of Materials Science under contract DE-FG05-89ER45384, and Beamline X-11 at the National Synchrotron Light Source, Brookhaven National Laboratory is supported by the US Department of Energy, Division of Materials Science under contract DE-AC02-76CH00016.

\section{References}

[1] Wang, Z., Hesterberg, D. , Zhou, W., Sayers, D. E. and Robarge, W. P., "Extended X-ray absorption fine structure study of mercury speciation in a flood plain soil", 3rd International Conference on the Biogeochemistry of Trace Elements, Paris 15-19 May, 1995, R. Prost et al. Eds. (accepted).

[2] Hesterberg, D., Sayers, D. E., Zhou, W., Robarge, W., Plummer, G. M. "XAFS characterization of copper in model aqueous systems of humic acid and illite", 9th International Conference on X-ray Absorption Fine Structure, Grenoble 26-30 August 1996, (submitted).

[3] Sposito, G., Lund, L. J. , Chang, A. C., Soil Sci. Soc. Am. J. 46 (1982) 260-264.

[4] Tessier, A., Campbell, P. G. C., Bisson, M. Analyt. Chem. 51 (1979) 844-851.

[5] Lindsay, W. L., Chemical equilibria in soils (John Wiley and Sons, New York, 1979) pp. 221-297. 